\title{
Examining Patterns and Drivers of Variability in Playa Water Status on the High Plains of Western Kansas, 2016-2019
}

\author{
Mark W. Bowen ${ }^{1}$ and Luis Lepe ${ }^{2}$ \\ ${ }^{1}$ Corresponding author: mark.bowen@mnsu.edu, Department of Geography and EARTH Systems Laboratory, Minnesota State University, Mankato \\ 2luis.lepe@mnsu.edu, Department of Geography and EARTH Systems Laboratory, Minnesota State University, Mankato
}

\begin{abstract}
Playa wetlands are widely distributed across the High Plains of the central United States, providing a range of ecosystem services, such as groundwater recharge, surface water storage, and wetland habitat. Although playas are essential resources, few studies have examined the variability and controls on playa water storage. The purpose of this project is to determine how playa and watershed morphology, watershed land cover, and precipitation patterns affect timing and duration of water storage in playas. This project focuses on 92 playas distributed throughout a 10-county region in western Kansas.

Playa and watershed morphology were calculated in a GIS environment and classified into quartiles based on playa and watershed surface area. Watershed tilled index (i.e., percent cropland versus grassland) was determined using 2016, 2017, 2018, and 2019 Cropland Data Layers available from the National Agricultural Statistics Service and classified as either cropland (more than $75 \%$ cropland), grassland (more than 75\% grassland), or mixed. Monthly precipitation data for 2016-2019 were compiled from the Oakley 22S High Plains Regional Climate Center weather station. Playa water status for 2016-2019 was classified monthly as either standing water or dry (i.e., no visible standing water) by visually examining four-band satellite imagery with $3.7 \mathrm{~m}$ resolution available from Planet Explorer (www.planet.com).

Playa water status is influenced by a combination of factors, including playa and watershed morphology, watershed land cover, and precipitation patterns. Larger playas have larger watersheds and standing water more frequently and for longer periods than smaller playas. Playas in cropland watersheds store water more frequently and for longer periods than playas in grassland watersheds, though differences are not statistically significant. Standing water within playas is positively correlated with monthly precipitation and reflects a short-term response to precipitation patterns, regardless of playa size or watershed land cover. The strongest controls on playa water status are playa area, monthly precipitation, and watershed area.

Playas are critical resources for the High Plains, providing a range of ecosystem services that are dependent upon the playa's ability to store water. Playa functions are under continued threat from
\end{abstract}

Midcontinent Geoscience • Volume 2・ July 2021

Midcontinent Geoscience is an open-access, peer-reviewed journal of the Kansas Geological Survey. The journal publishes original research on a broad array of geoscience topics, with an emphasis on the midcontinent region of the United States, including the Great Plains and Central Lowland provinces. 
cropland expansion, climate change, and playa and watershed modifications. To sustain playa functions in Kansas, efforts should focus on conserving larger grassland playas and reducing sediment inputs to playas in cropland watersheds.

\section{INTRODUCTION}

Playa wetlands are widely distributed across the High Plains of the central United States, with about 25,000 playas on the Southern High Plains (Sabin and Holliday, 1995) and more than 20,000 playas on the Central High Plains (Bowen et al., 2010). Playas are critical resources for the region, providing a range of ecosystem services, such as groundwater recharge, surface water storage, and wetland habitat (Smith et al., 2011). The High Plains aquifer is the largest freshwater aquifer in the United States (Sophocleous, 2005), providing about 30\% of the nation's irrigation groundwater (Dennehy et al., 2002) and more than $70 \%$ of all water used in the state of Kansas (Buchanan et al., 2015). As a result of this intensive use, primarily to support irrigation-based agriculture, the entire High Plains aquifer has declined on average by nearly $5 \mathrm{~m}$, with local declines exceeding $70 \mathrm{~m}$, since the 1950s (McGuire, 2017). In the state of Kansas, High Plains aquifer declines are in excess of $50 \mathrm{~m}$ for much of southern Kansas, with an area-weighted average decline of $8 \mathrm{~m}$ for the entire state (McGuire, 2017). Groundwater recharge from playas is essential to reduce aquifer declines, with recharge rates one to two orders of magnitude greater within playas than the surrounding uplands (Gurdak and Roe, 2010).

Groundwater declines have had dramatic impacts on surface water resources. Surface water hydrology is directly affected by aquifer conditions because of hydraulic connections between the High Plains aquifer and several of the major river systems that traverse the High Plains, such as the Arkansas River and Cimarron River in Kansas (Weeks, 1988). Declines in the High Plains aquifer have resulted in significant, long-term declines in stream flow and an increase in the number of days with no to low flow for streams in Kansas (Kustu et al., 2010). Due to widespread conversion of prairie ecosystems to row-crop agriculture, playas are the only source of surface water and natural habitat remaining to support biodiversity in many areas (Smith et al., 2011). Playas represent the only aquatic habitat for extensive portions of the High Plains and can increase biodiversity by more than $300 \%$ compared to regions on the High Plains without playas (Smith, 2003).
The greatest threat to playa function is accelerated accumulation of sediment due to conversion of native prairie to cultivated cropland (Smith, 2003). Approximately $30 \%$ of the High Plains has been converted to cultivated cropland (Hartman et al., 2011). Expansion of cropland has increased in recent years, particularly within western Kansas, primarily as a result of conversion from long-term grassland (Lark et al., 2015). Given the extent of cultivated cropland and the continued conversion of grassland to cropland on the High Plains, playas are receiving increased sediment inputs, resulting in loss of playa water storage volume. In Kansas, playas within cropland watersheds have lost more than $30 \%$ of their original storage volume (Bowen and Johnson, 2017), while cropland playas on the Southern High Plains have lost up to $100 \%$ of their storage volume (Luo et al., 1997). Tsai et al. (2007) found that on the Southern High Plains, playas with cropland-dominated watersheds had higher water loss rates and shorter hydroperiods than playas in grassland watersheds. They partially attributed this to increased sediment accumulation within playas decreasing water depth and increasing water surface area, resulting in greater evaporation rates.

Projected climate change is also likely to have a dramatic impact on playa water storage over the coming decades. The frequency and intensity of large storms have been increasing over the past 50 years and are projected to continue to increase (Easterling et al., 2017). Precipitation events are likely to be concentrated in fewer days, with longer dry periods and projected declines in summer rainfall and winter snowfall (Shafer et al., 2014). Additionally, regional temperatures are projected to increase $2^{\circ} \mathrm{C}$ by 2050 and as much as $6.5^{\circ} \mathrm{C}$ by 2090 (Vose et al., 2017), with the number of days over $37.8^{\circ} \mathrm{C}$ $\left(100^{\circ} \mathrm{F}\right)$ expected to more than double this century (Shafer et al., 2014). Increases in regional temperature, with a decline in the number of precipitation days, including less precipitation during the summer growing season, would likely enhance evapotranspiration rates and result in declining water storage and groundwater recharge within playas.

Although playas are essential resources that are under threat by continued expansion of cultivated cropland and climate change, few studies have examined patterns in and controls on playa water storage. The purpose of this project is to determine how playa and watershed morphology, watershed land cover, and precipitation patterns affect timing and duration of water storage in playas. Primary objectives are to 1) delineate watersheds and measure playa and watershed morphology for 92 playas on the High 
Plains of western Kansas; 2) calculate watershed land cover from 2016 to 2019 for each playa; and 3) track monthly variability in playa water status (i.e., dry or standing water) during this period. To accomplish these objectives, this project employed geographic information systems (GIS) and remote sensing techniques.

\section{STUDY AREA}

This project focuses on 92 playas distributed throughout a 10-county region in western Kansas (Finney, Gove, Greeley, Lane, Logan, Scott, Sherman, Thomas, Wallace, and Wichita counties) (table 1 and fig. 1). The region is classified as a cold, semi-arid steppe (BSk) climate (Peel et al., 2007). Precipitation at Scott City, centrally located within the study area (fig. 1), has averaged $51 \mathrm{~cm}$ per year since 1908, with more than two-thirds delivered from April to August (High Plains Regional Climate Center, 2020). Mean annual temperature since 1895 has averaged $12.3^{\circ}$ C. Native vegetation is primarily composed of short-grass prairie grasses such as blue gramma (Bouteloua gracilis) and buffalograss (Bouteloua dactyloides) (Kuchler, 1974). The majority of the landscape is used for agricultural purposes, with the Central High Plains consisting of about $67 \%$ cropland and 30\% grazing lands (U.S. Department of Agriculture Natural Resources Conservation Service, 2006). Within the study area, percent of county in farmland in 2017 ranged from $76 \%$ to $100 \%$ and percent of county in harvested cropland ranged from $31 \%$ to $56 \%$ (table 1) (Kansas Department of Agriculture, 2019).

More than 22,000 playas have been mapped in western Kansas (Bowen et al., 2010). The 10-county study region contains 11,947 mapped playas (table 1 and fig. 1). Of the 92 playas included in this study, 64 were previously examined by Bowen and Johnson (2017) to calculate the amount of sediment stored within playas. Sites were selected based

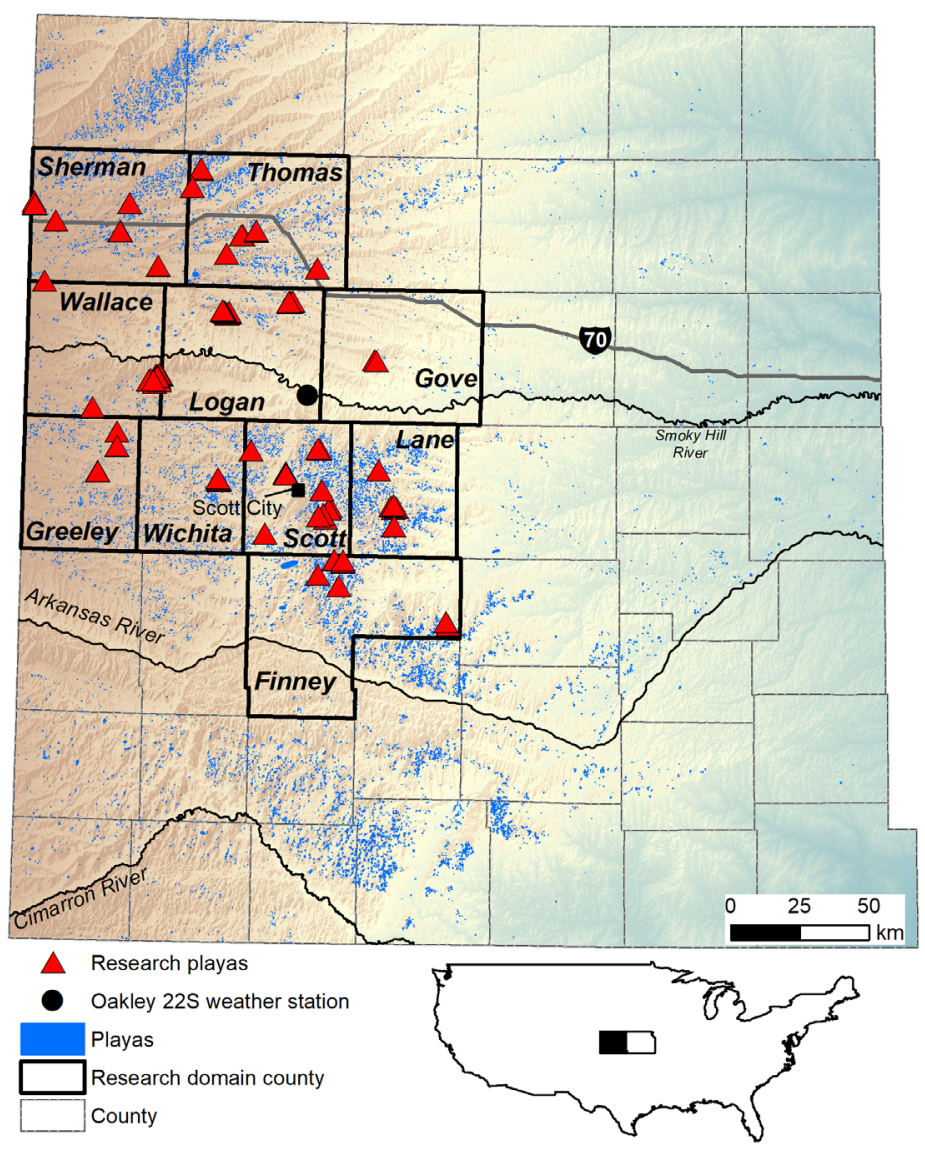

Figure 1. Distribution of research playas $(n=92)$ and Oakley $22 S$ weather station in western Kansas.

Table 1. Distribution of playas, land in farms, and harvested cropland in the 10-county study region in western Kansas.

\begin{tabular}{|c|c|c|c|c|c|c|}
\hline County & $\begin{array}{l}\text { Number } \\
\text { of Playas }^{1}\end{array}$ & $\begin{array}{l}\text { County Area } \\
\text { (ha) }^{2}\end{array}$ & $\begin{array}{l}\text { Land in Farms } \\
2017 \text { (ha) }{ }^{3}\end{array}$ & $\begin{array}{l}\text { Percent County } \\
\text { Land in Farms } 2017\end{array}$ & $\begin{array}{c}\text { Harvested } \\
\text { Cropland } 2017(\mathrm{ha})^{3}\end{array}$ & $\begin{array}{c}\text { Percent County } \\
\text { Harvested } \\
\text { Cropland } 2017 \\
\end{array}$ \\
\hline Finney & 1,626 & 337,216 & 319,904 & 94.9 & 182,845 & 54.2 \\
\hline Gove & 145 & 277,647 & 229,636 & 82.7 & 91,316 & 32.9 \\
\hline Greeley & 886 & 201,501 & 192,178 & 95.4 & 97,943 & 48.6 \\
\hline Lane & 1,820 & 185,702 & 168,761 & 90.9 & 60,456 & 32.6 \\
\hline Logan & 379 & 277,906 & 244,761 & 88.1 & 88,446 & 31.8 \\
\hline Scott & 2,116 & 185,961 & 186,292 & 100 & 102,395 & 55.1 \\
\hline Sherman & 1,373 & 273,503 & 250,269 & 91.5 & 118,702 & 43.4 \\
\hline Thomas & 2,041 & 278,424 & 271,115 & 97.4 & 156,395 & 56.2 \\
\hline Wallace & 330 & 236,725 & 180,413 & 76.2 & 72,813 & 30.8 \\
\hline Wichita & 1,231 & 186,220 & 177,230 & 95.2 & 92,056 & 49.4 \\
\hline
\end{tabular}

${ }^{1}$ Bowen et al., 2010; ${ }^{2}$ Gunter et al., 2019; ${ }^{3}$ Kansas Department of Agriculture, 2019 
on minimal change in watershed land cover from 2016 through 2019. All playas included in this study were visible on aerial imagery and confirmed on the ground via roadside surveys; 72 were mapped on 1:24,000-scale topographic maps as water bodies and / or depression contours. Most playas $(\mathrm{n}=59)$ had a SSURGO soil map unit distinct from the surrounding uplands, consisting of Ness clay (Ustic Epiaquerts) or Pleasant silty clay loam (Torrertic Argiustolls).

\section{METHODS}

Playas were selected for this study by visually examining color aerial imagery collected as part of the National Agriculture Imagery Program (NAIP) for the years 2015, 2017, and 2019, and clusters of playas within regions of little to no land cover change were included. Playa watersheds were delineated by heads-up digitizing in a GIS environment by following drainage divides on 1:24,000 digital raster graphics (DRGs) and LiDAR-derived digital elevation models (DEMs). The initial playa population included 123 sites. Outliers identified following the "1.5 times the interquartile range $\left(1.5^{*} \mathrm{IQR}\right)$ " rule (Hoaglin et al., 1986) based on playa or watershed morphometric variables were removed from the population; 31 outliers were removed for a total of 92 playas included in this study. Of the 31 outliers removed, 15 had a playa area that exceeded the $1.5^{\star} \mathrm{IQR}$ rule ( 10 of these also had watersheds that exceeded the rule), and 8 were removed because the watershed area was too large. The $1.5^{\star} \mathrm{IQR}$ rule was used because of its simplicity and robustness, and it approximately corresponds with 3 standard deviations from the median, so only extreme values are removed (Barbato et al., 2011).

Playa and watershed morphometry were calculated using geospatial functions in ArcGIS 10.5. Playa and watershed area and perimeter were calculated using the "Calculate Geometry" function. Playa and watershed circularity were computed using the "Field Calculator" and the following equation:

$$
\text { Circularity }=4^{*} \pi^{*}\left(\text { Area / Perimeter }{ }^{2}\right)
$$

Circularity ranges from 0.0 to 1.0 , with a perfect circle having a value of 1.0; as a feature becomes more elongate, the value decreases (Miller, 1953). Based on playa area and watershed area, sites were divided into size classes by quartile. Watershed mean slope was estimated using one-third arc-second National Elevation Dataset DEMs and the "Spatial Analyst Extension." Watershed and playa size and shape and watershed slope influence overland flow patterns and could greatly affect playa water status.

Watershed land cover was mapped using the 2016, 2017, 2018, and 2019 Cropland Data Layers (CDL) available from the National Agricultural Statistics Service (https: / / nassgeodata.gmu.edu/CropScape/). Land cover was classified as (1) cropland, which included all crop types and fallow land, or (2) grassland, which included perennial grassland, shrubland, barren, pasture, open water and wetlands (typically the playa), and forest/ deciduous (typically fence rows, small patches of trees, or misclassified grassland based on examining aerial imagery). Native grassland and Conservation Reserve Program (CRP) grasslands are not differentiated in CDL and could not be differentiated for this study. Watershed tilled index (TI) was calculated for each playa for each year using the following equation:

$$
\begin{gathered}
\mathrm{TI}=(\text { cropland area }- \text { grassland area }) \\
(\text { cropland area }+ \text { grassland area })
\end{gathered}
$$

(Tsai et al., 2007). Based on watershed TI, research sites were divided into three classes: grassland (TI $<-0.5$; i.e., watershed more than $75 \%$ grassland), cropland (TI $>0.5$; i.e., watershed more than $75 \%$ cropland), and mixed ( -0.5 $<\mathrm{TI}<0.5$; i.e., watershed more than $25 \%$ grassland and cropland).

Monthly precipitation data for the years 2016-2019 were compiled from the Oakley 22S High Plains Regional Climate Center weather station, located near the center of the research area (fig. 1). Precipitation at this station has been recorded continuously since 1989, providing a 31-year record. To compare annual precipitation for each year of analysis (i.e., 2016-2019) to long-term trends, 28- to 30-year moving average precipitation was computed (i.e., 19892016, 1989-2017, 1989-2018, 1990-2019).

Playa water status for 2016-2019 was classified monthly by visually examining four-band (red, green, blue, and near infrared) PlanetScope monthly mosaic satellite imagery with $3.7 \mathrm{~m}$ resolution and predefined image enhancements available from Planet Explorer (www.planet. com). Planet Explorer is an online tool to examine and analyze geospatial imagery across a range of spatial and temporal scales within a web browser. PlanetScope imagery is collected daily within the study area, and monthly mosaic imagery provides the best quality image for each month by combining daily images to eliminate atmospheric disturbances and corrupted images. Pre-defined image enhancements are available within Planet Explorer to 
adjust for contrast, brightness, and saturation. These enhancements aided in the classification of playa water status. Playa water status was classified as follows: $0=$ no data / not able to classify; 1 = dry (i.e., no visible standing water) based on light tones or mottled colors on imagery; or 2 standing water based on uniform dark tones with clear boundaries (fig. 2).

Classification was initially performed independently by both authors. Classification datasets were compared, and it was determined that the authors differed on only 53 (1.2\%) of the 4,416 observations (92 playas $x 48$ months). The authors reexamined the 53 observations together and agreed on classification for 43 of those observations; discrepancies in classification were primarily due to user error (i.e., examining the wrong playa or wrong month). The remaining 10 observations were assigned a score of 0 (i.e., not able to classify).

Statistical analyses were conducted using the software package SPSS (IBM SPSS Statistics Version 27). Bivariate correlation analysis was conducted to assess relationships among playa and watershed morphometry, land cover, precipitation, and playa water status. Regression analysis was performed to determine the degree of influence of playa and watershed morphology, land cover, and precipitation on playa water status. One-way analysis of variance (ANOVA) was conducted to compare differences in playa and watershed morphometry, watershed TI, and playa water status by county, TI cover class (i.e., cropland, grassland, and mixed), and size class (i.e., playa/ watershed area by quartile). Statistically significant differences in ANOVA were evaluated using the Tukey honest significance difference (HSD) test to determine which classes exhibited significant differences. Greeley and Wichita counties and Logan and Gove counties were combined due to the small number of playas in Greeley, Wichita, and Gove counties.

\section{RESULTS}

Playa and Watershed Morphology

Playas included in this study represent a range of playa and watershed morphologies, but most playas and associated watersheds are relatively small and circular (table 2). Playa surface area ranges from 0.13 ha to 7.73 ha among all 92 sites, with mean and median values of 2.40 ha and 1.94 ha, respectively. Playa circularity ranges from 0.57 to 0.97 , and mean circularity is 0.86 . Watersheds are also generally small, low relief, and circular. Watershed area ranges from 3.2 ha to 294.9 ha with mean and median values of 58.7 ha and $42.3 \mathrm{ha}$, respectively. Watershed mean

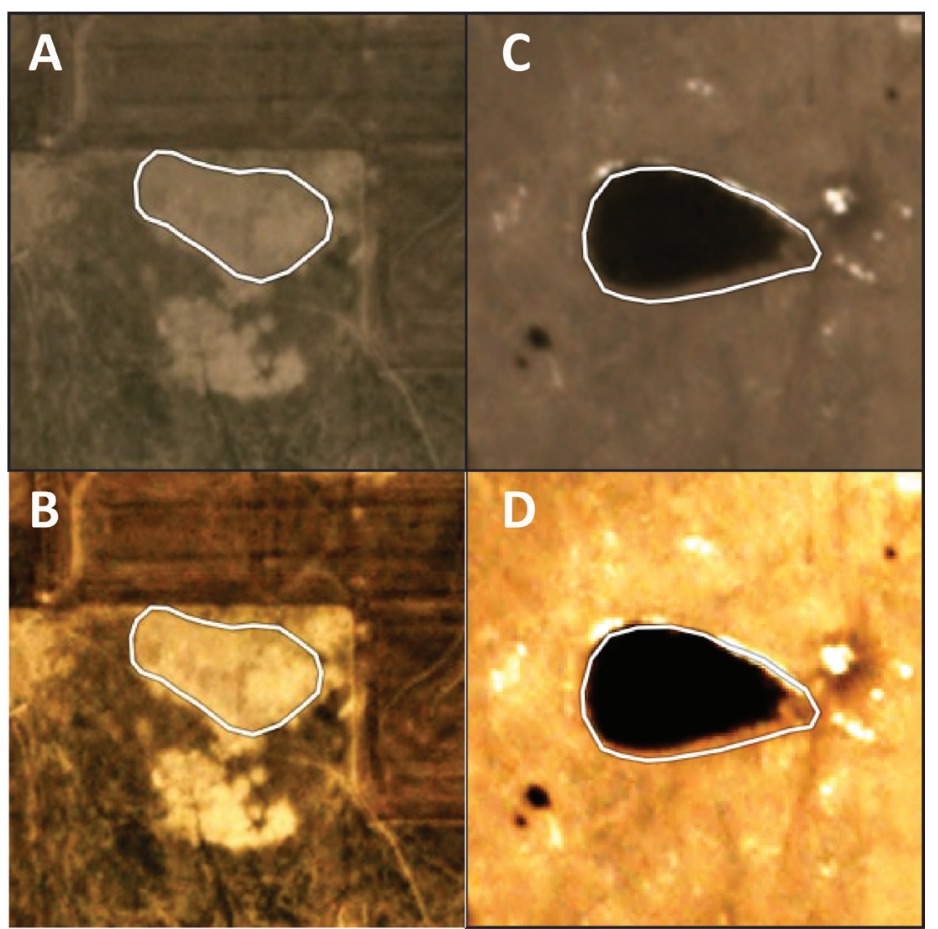

Figure 2. PlanetScope monthly mosaic satellite imagery providing examples of playa water status categories: (a) dry playa; (b) dry playa with image enhancement; (c) playa with standing water; and (d) playa with standing water and image enhancement.

slope ranges from only $0.3 \%$ to $1.4 \%$, and mean slope is only $0.68 \%$. Watershed circularity ranges from 0.36 to 0.91 , with a mean of 0.66 .

Playa and watershed morphology are highly correlated (table 3). Playa area and perimeter $(\mathrm{r}=0.964, \mathrm{P}<0.001)$ and watershed area and perimeter $(\mathrm{r}=0.942, \mathrm{P}<0.001)$ are highly significantly positively correlated, so perimeter is excluded from further analyses. Playa area is also significantly correlated with playa circularity $(\mathrm{r}=-0.246$, $\mathrm{P}=0.018)$ and watershed area $(\mathrm{r}=0.624, \mathrm{P}<0.001)$. Playa circularity is significantly negatively correlated with playa area, so larger playas are typically less circular. Playa area and watershed area are positively correlated, so larger playas are typically situated in larger watersheds.

Playa and watershed morphology are generally similar among the three different TI classes (table 2). The only significant differences are with playa circularity and watershed mean slope (table 4). Playa circularity minimum and maximum values are nearly identical for all three TI classes (table 2), and mean playa circularity by TI class ranges from 0.80 to 0.88 . This slight difference in playa circularity is assumed to have little to no impact on playa water status, as playas in the three TI classes are generally circular. Watershed mean slope ranges from only $0.30 \%$ to $1.42 \%$ among all sites, while class-average mean slope 
Table 2. Summary of playa and watershed morphometric variables for all 92 playas by playa surface area quartile size class, watershed area quartile size class, and watershed tilled index class (i.e., cropland, grassland, and mixed).

\begin{tabular}{|c|c|c|c|c|c|c|c|c|}
\hline & & $\begin{array}{c}\text { Playa } \\
\text { Area (ha) }\end{array}$ & $\begin{array}{c}\text { Playa } \\
\text { Perimeter (m) }\end{array}$ & $\begin{array}{c}\text { Playa } \\
\text { Circularity }\end{array}$ & $\begin{array}{l}\text { Watershed } \\
\text { Area (ha) }\end{array}$ & $\begin{array}{c}\text { Watershed } \\
\text { Perimeter (m) }\end{array}$ & $\begin{array}{l}\text { Watershed } \\
\text { Circularity }\end{array}$ & $\begin{array}{c}\text { Watershed } \\
\text { Mean Slope (\%) }\end{array}$ \\
\hline \multirow{4}{*}{$\begin{array}{l}\text { All sites } \\
(n=92)\end{array}$} & Min & 0.13 & 131.18 & 0.57 & 3.22 & $1,053.19$ & 0.36 & 0.30 \\
\hline & Max & 7.73 & $1,134.29$ & 0.97 & 294.86 & $7,575.67$ & 0.91 & 1.42 \\
\hline & Mean & 2.40 & 553.42 & 0.86 & 58.70 & $3,145.61$ & 0.66 & 0.68 \\
\hline & Median & 1.94 & 531.35 & 0.89 & 42.30 & $2,940.88$ & 0.66 & 0.64 \\
\hline \multicolumn{9}{|c|}{ Playa Size Class } \\
\hline \multirow{4}{*}{$\begin{array}{l}\text { Quartile } 1 \\
(n=23)\end{array}$} & Min & 0.13 & 131.18 & 0.62 & 3.22 & $1,053.19$ & 0.37 & 0.32 \\
\hline & Max & 0.86 & 347.11 & 0.97 & 70.54 & $4,462.29$ & 0.85 & 1.42 \\
\hline & Mean & 0.50 & 257.66 & 0.91 & 26.34 & $2,181.47$ & 0.66 & 0.63 \\
\hline & Median & 0.47 & 256.22 & 0.95 & 17.75 & $1,695.33$ & 0.65 & 0.59 \\
\hline \multirow{4}{*}{$\begin{array}{l}\text { Quartile } 2 \\
(n=23)\end{array}$} & Min & 0.87 & 341.74 & 0.60 & 7.50 & $1,078.19$ & 0.36 & 0.39 \\
\hline & Max & 1.87 & 526.30 & 0.97 & 89.66 & $5,129.18$ & 0.91 & 0.97 \\
\hline & Mean & 1.33 & 438.45 & 0.87 & 32.13 & $2,451.15$ & 0.65 & 0.66 \\
\hline & Median & 1.31 & 443.17 & 0.89 & 27.04 & $2,349.43$ & 0.64 & 0.66 \\
\hline \multirow{4}{*}{$\begin{array}{l}\text { Quartile } 3 \\
(n=23)\end{array}$} & Min & 2.01 & 536.40 & 0.57 & 11.43 & $1,568.86$ & 0.36 & 0.33 \\
\hline & Max & 3.45 & 795.48 & 0.97 & 141.14 & $5,681.79$ & 0.88 & 1.31 \\
\hline & Mean & 2.60 & 631.21 & 0.83 & 62.33 & $3,411.87$ & 0.65 & 0.73 \\
\hline & Median & 2.56 & 618.73 & 0.88 & 58.21 & $3,422.37$ & 0.64 & 0.70 \\
\hline \multirow{4}{*}{$\begin{array}{l}\text { Quartile } 4 \\
(n=23)\end{array}$} & Min & 3.52 & 744.60 & 0.62 & 32.89 & $2,276.05$ & 0.51 & 0.30 \\
\hline & Max & 7.73 & $1,134.29$ & 0.96 & 294.86 & $7,575.67$ & 0.83 & 1.27 \\
\hline & Mean & 5.19 & 886.38 & 0.83 & 114.00 & $4,537.93$ & 0.67 & 0.70 \\
\hline & Median & 4.98 & 898.18 & 0.84 & 108.78 & $4,492.01$ & 0.67 & 0.61 \\
\hline \multicolumn{9}{|c|}{ Watershed Size Class } \\
\hline \multirow{4}{*}{$\begin{array}{l}\text { Quartile } 1 \\
(n=23)\end{array}$} & Min & 0.13 & 131.18 & 0.62 & 3.22 & $1,053.19$ & 0.36 & 0.32 \\
\hline & Max & 2.44 & 566.93 & 0.97 & 20.99 & $2,346.13$ & 0.91 & 1.42 \\
\hline & Mean & 0.93 & 338.62 & 0.89 & 13.24 & $1,529.41$ & 0.71 & 0.64 \\
\hline & Median & 0.78 & 338.71 & 0.93 & 12.34 & $1,508.80$ & 0.76 & 0.61 \\
\hline \multirow{4}{*}{$\begin{array}{l}\text { Quartile } 2 \\
(n=23)\end{array}$} & Min & 0.38 & 223.14 & 0.60 & 21.45 & $1,824.68$ & 0.38 & 0.33 \\
\hline & Max & 7.00 & $1,067.37$ & 0.97 & 42.23 & $3,648.90$ & 0.91 & 1.04 \\
\hline & Mean & 2.08 & 518.07 & 0.87 & 31.37 & $2,536.24$ & 0.64 & 0.64 \\
\hline & Median & 1.55 & 484.68 & 0.92 & 31.43 & $2,479.66$ & 0.58 & 0.65 \\
\hline \multirow{4}{*}{$\begin{array}{l}\text { Quartile 3 } \\
(\mathrm{n}=23)\end{array}$} & Min & 0.38 & 222.09 & 0.57 & 42.37 & $2,529.93$ & 0.36 & 0.39 \\
\hline & Max & 7.73 & $1,065.89$ & 0.97 & 76.27 & $4,881.75$ & 0.91 & 1.31 \\
\hline & Mean & 2.33 & 566.73 & 0.83 & 58.17 & $3,391.50$ & 0.66 & 0.74 \\
\hline & Median & 2.09 & 578.73 & 0.85 & 58.25 & $3,262.18$ & 0.64 & 0.70 \\
\hline
\end{tabular}




\begin{tabular}{|c|c|c|c|c|c|c|c|c|}
\hline & & $\begin{array}{c}\text { Playa } \\
\text { Area (ha) }\end{array}$ & $\begin{array}{c}\text { Playa } \\
\text { Perimeter (m) }\end{array}$ & $\begin{array}{c}\text { Playa } \\
\text { Circularity }\end{array}$ & $\begin{array}{l}\text { Watershed } \\
\text { Area (ha) }\end{array}$ & $\begin{array}{c}\text { Watershed } \\
\text { Perimeter }(\mathrm{m})\end{array}$ & $\begin{array}{l}\text { Watershed } \\
\text { Circularity }\end{array}$ & $\begin{array}{c}\text { Watershed } \\
\text { Mean Slope (\%) }\end{array}$ \\
\hline \multirow{4}{*}{$\begin{array}{l}\text { Quartile } 4 \\
(n=23)\end{array}$} & Min & 1.09 & 400.45 & 0.70 & 79.63 & $3,703.92$ & 0.42 & 0.30 \\
\hline & Max & 7.13 & $1,134.29$ & 0.95 & 294.86 & $7,575.67$ & 0.85 & 1.23 \\
\hline & Mean & 4.28 & 790.28 & 0.84 & 132.03 & $5,125.28$ & 0.64 & 0.69 \\
\hline & Median & 4.46 & 786.44 & 0.85 & 119.23 & $5,107.88$ & 0.65 & 0.61 \\
\hline \multicolumn{9}{|c|}{ Tilled Index Class } \\
\hline \multirow{4}{*}{$\begin{array}{l}\text { Cropland } \\
(n=54)\end{array}$} & Min & 0.13 & 131.18 & 0.57 & 3.22 & $1,053.19$ & 0.37 & 0.30 \\
\hline & Max & 7.13 & $1,134.29$ & 0.97 & 161.82 & $6,293.90$ & 0.91 & 1.23 \\
\hline & Mean & 2.49 & 558.65 & 0.88 & 61.87 & $3,277.00$ & 0.64 & 0.59 \\
\hline & Median & 2.15 & 540.37 & 0.91 & 44.54 & $3,048.77$ & 0.63 & 0.54 \\
\hline \multirow{4}{*}{$\begin{array}{l}\text { Grassland } \\
(n=24)\end{array}$} & Min & 0.15 & 137.40 & 0.58 & 7.50 & $1,077.37$ & 0.36 & 0.45 \\
\hline & Max & 6.72 & 987.91 & 0.97 & 294.86 & $7,575.67$ & 0.88 & 1.22 \\
\hline & Mean & 2.02 & 506.76 & 0.84 & 51.10 & $2,820.00$ & 0.68 & 0.78 \\
\hline & Median & 1.32 & 440.45 & 0.86 & 30.48 & $2,204.23$ & 0.69 & 0.74 \\
\hline \multirow{4}{*}{$\begin{array}{l}\text { Mixed } \\
(\mathrm{n}=14)\end{array}$} & Min & 0.38 & 222.09 & 0.60 & 14.42 & $1,494.05$ & 0.53 & 0.40 \\
\hline & Max & 7.73 & $1,067.37$ & 0.97 & 212.34 & $7,025.22$ & 0.86 & 1.42 \\
\hline & Mean & 2.75 & 613.24 & 0.80 & 59.51 & $3,196.97$ & 0.70 & 0.84 \\
\hline & Median & 2.04 & 561.38 & 0.84 & 49.80 & $3,114.84$ & 0.70 & 0.80 \\
\hline
\end{tabular}

is $0.59 \%$ for cropland, $0.78 \%$ for grassland, and $0.84 \%$ for mixed watersheds (table 2). Thus, cropland watershed mean slope is slightly lower than grassland and mixed watersheds. Given class-average mean slope differs by only 0.25 percentage point among the three classes, impacts of differences in slope on playa water status by TI class are assumed to be minimal, and playa and watershed morphology can be considered equivalent for the three TI classes.

Playa and watershed morphology are also generally similar among the counties even though there are significant differences for all variables except watershed circularity (table 4). Playas and watersheds in Finney County are significantly larger than Logan/Gove and Wallace counties, which include several playas and watersheds in the two smallest size classes. Playas and watersheds in Lane County are significantly larger than all counties except Finney and Thomas counties; six of the seven playas and watersheds in Lane County are in the largest size class. Thus, playas and watersheds in Finney and Lane counties are in general larger than other counties, while most other playas and watersheds are similar in size. Playas in Gove/Logan and Wallace counties are slightly more circular than playas in Greeley/Wichita, Scott, and Sherman counties, though mean circularity values differ by only 0.16 and all are greater than 0.75 , indicating playas in all counties are generally circular in shape. Watershed mean slope in Sherman County $(0.93 \%)$ is significantly steeper than watersheds in Scott $(0.61 \%)$, Lane $(0.55 \%)$, and Logan/Gove $(0.55 \%)$ counties, though all mean slopes are less than $1 \%$.

\section{Watershed Land Cover}

Of the 92 playas included in this study, 54 have cropland watersheds, 24 have grassland watersheds, and 14 have mixed watersheds (table 5). Watershed land cover was relatively constant for the four-year period among all sites, with TI varying by more than 0.1 at only three sites. Variability was not great enough at any site to be classified in a different TI class during the four-year period.

Differences in mean watershed TI are significant among the three TI classes $(\mathrm{F}(2,89)=1,030.5, \mathrm{P}<0.001)$. Mean watershed TI is 0.93 (i.e., $96.5 \%$ cropland) among cropland sites, -0.86 (i.e., $93 \%$ grassland) among grassland sites, and 0.01 (i.e., 50\% cropland and grassland) among mixed sites. Of the 54 cropland sites, 32 have watersheds composed of $100 \%$ cropland, while only 7 of the 24 grassland sites have watersheds composed of $100 \%$ grassland. Differences in mean watershed TI by county are significant $(F(7,84)=$ $5.531, \mathrm{P}<0.001)$, but only Logan County has a significantly 
Table 3. Bivariate correlation matrix of playa and watershed morphometric variables. Bold numbers are significant at $p<0.05$; bold and italic numbers are significant at $p<0.01$.

\begin{tabular}{|c|c|c|c|c|c|c|c|}
\hline & & Playa Area & Playa Perimeter & Playa Circularity & $\begin{array}{c}\text { Watershed } \\
\text { Area }\end{array}$ & $\begin{array}{l}\text { Watershed } \\
\text { Perimeter }\end{array}$ & $\begin{array}{l}\text { Watershed } \\
\text { Circularity }\end{array}$ \\
\hline \multirow[t]{2}{*}{ Playa Perimeter } & r & 0.964 & & & & & \\
\hline & $P$ & 0.000 & & & & & \\
\hline \multirow[t]{2}{*}{ Playa Circularity } & r & -0.246 & -0.424 & & & & \\
\hline & $P$ & 0.018 & 0.000 & & & & \\
\hline \multirow[t]{2}{*}{ Watershed Area } & r & 0.624 & 0.623 & -0.166 & & & \\
\hline & $P$ & 0.000 & 0.000 & 0.113 & & & \\
\hline \multirow[t]{2}{*}{ Watershed Perimeter } & r & 0.568 & 0.582 & -0.134 & 0.942 & & \\
\hline & $P$ & 0.000 & 0.000 & 0.203 & 0.000 & & \\
\hline \multirow[t]{2}{*}{ Watershed Circularity } & r & 0.093 & 0.098 & -0.172 & -0.146 & -0.367 & \\
\hline & $P$ & 0.377 & 0.352 & 0.102 & 0.165 & 0.000 & \\
\hline \multirow[t]{2}{*}{ Watershed Mean Slope } & $r$ & -0.014 & 0.081 & -0.287 & 0.099 & 0.052 & 0.197 \\
\hline & $P$ & 0.898 & 0.445 & 0.006 & 0.346 & 0.622 & 0.060 \\
\hline
\end{tabular}

Table 4. Results of one-way ANOVA comparing mean differences in playa and watershed morphometric variables by watershed tilled index class (i.e., cropland, grassland, and mixed) and county. Bold numbers are significant at $p<0.05$; bold and italic numbers are significant at $p<0.01$.

\begin{tabular}{lcccc}
\hline & \multicolumn{2}{c}{ Tilled Index Class } & \multicolumn{2}{c}{ County } \\
\hline Morphometric variable & F value & P value & F value & \multicolumn{1}{c}{ P value } \\
\hline Playa area & 0.767 & 0.467 & $\mathbf{7 . 3 8 3}$ & $\mathbf{0 . 0 0 0}$ \\
Playa circularity & 3.165 & 0.047 & $\mathbf{6 . 3 1 3}$ & $\mathbf{0 . 0 0 0}$ \\
Watershed area & 0.360 & 0.698 & $\mathbf{2 . 5 2 8}$ & $\mathbf{0 . 0 2 1}$ \\
Watershed circularity & 1.094 & 0.339 & 2.031 & 0.060 \\
Watershed mean slope & $\mathbf{1 0 . 0 5 9}$ & $\mathbf{0 . 0 0 0}$ & $\mathbf{4 . 2 2 2}$ & $\mathbf{0 . 0 0 0}$ \\
\hline
\end{tabular}

different mean watershed TI than the other counties. All playas in Logan County are within the cropland cover class with a mean watershed TI of 0.99 , while playas in other counties have a broader range of watershed TI.

\section{Precipitation}

Precipitation recorded at Oakley 22S from 2016 to 2019 is similar to long-term average precipitation for the station (fig. 3), with only two months (April 2016 and March 2017) receiving more than 1.5 times the interquartile range.

While seasonal trends in precipitation are similar from year to year, with little to no precipitation during winter and maximum precipitation during late spring and summer, annual precipitation is variable. Annual precipitation from 2016 to 2019 ranges from $39.3 \mathrm{~cm}$ in 2016 to $53.2 \mathrm{~cm}$ in 2017, while mean annual precipitation for the period of record (i.e., 1989-2019) is $46.9 \mathrm{~cm}$. Three of the four years are drier than the long-term average, with 2016 receiving about $17 \%$ less than average, 2018 receiving about $14 \%$ less, and 2019 receiving about 5\% less. Only 2017 precipitation is greater than the long-term average, and at $53.2 \mathrm{~cm}$ it received about $12 \%$ more than the long-term average. Thus, the period from 2016 to 2019 represents a range of climatic conditions, with 2016 and 2018 much drier than average, 2019 precipitation similar to average, and 2017 much wetter than average.

Winter 2018-2019 is the only period in which significant snowfall was received. The High Plains Regional Climate Center weather station at Scott City, about $50 \mathrm{~km}$ south of the Oakley $22 \mathrm{~S}$ weather station, recorded $97.5 \mathrm{~cm}$ 
Table 5. Summary of watershed tilled index for 2016-2019 and the four-year mean tilled index by tilled index class (i.e., cropland, grassland, and mixed).

\begin{tabular}{|c|c|c|c|c|c|c|}
\hline & & $\begin{array}{l}\text { Tilled Index } \\
\quad 2016\end{array}$ & $\begin{array}{l}\text { Tilled Index } \\
2017\end{array}$ & $\begin{array}{l}\text { Tilled Index } \\
\quad 2018\end{array}$ & $\begin{array}{c}\text { Tilled Index } \\
2019\end{array}$ & $\begin{array}{l}\text { Mean Tilled } \\
\text { Index }\end{array}$ \\
\hline \multirow[t]{4}{*}{ Cropland $(n=54)$} & Min & 0.53 & 0.55 & 0.55 & 0.55 & 0.55 \\
\hline & Max & 1.00 & 1.00 & 1.00 & 1.00 & 1.00 \\
\hline & Mean & 0.92 & 0.93 & 0.93 & 0.94 & 0.93 \\
\hline & Median & 1.00 & 1.00 & 1.00 & 1.00 & 1.00 \\
\hline \multirow[t]{4}{*}{ Grassland $(n=24)$} & Min & -1.00 & -1.00 & -1.00 & -1.00 & -1.00 \\
\hline & Max & -0.55 & -0.55 & -0.55 & -0.55 & -0.55 \\
\hline & Mean & -0.86 & -0.86 & -0.86 & -0.86 & -0.86 \\
\hline & Median & -0.89 & -0.91 & -0.90 & -0.89 & -0.89 \\
\hline \multirow[t]{4}{*}{ Mixed (n=14) } & Min & -0.38 & -0.38 & -0.38 & -0.39 & -0.38 \\
\hline & Max & 0.39 & 0.39 & 0.39 & 0.39 & 0.39 \\
\hline & Mean & 0.01 & 0.01 & 0.01 & 0.01 & 0.01 \\
\hline & Median & 0.01 & -0.01 & -0.01 & 0.03 & 0.00 \\
\hline
\end{tabular}

of snowfall from October 2018 to March 2019. Based on examination of satellite imagery, snowfall was widely distributed across the study area.

\section{Playa Water Status}

During the 2016-2019 study period, playas were dry in $87.8 \%$ of all observations and had standing water in $12.2 \%$ of observations. In 2016, playas were dry in 97.3\% of observations and had standing water in only $2.3 \%$ of observations (fig. 4). Playas were dry in $85.5 \%$ of observations in 2017 and had standing water in 14.5\%. Observations in 2018 indicate $91.4 \%$ dry and $8.6 \%$ standing water. The fewest dry and greatest standing water observations were recorded in 2019 at $76.5 \%$ and $23.5 \%$, respectively.

Seasonal trends in water status over time are generally similar among playa size class (fig. 5). However, playas in the smallest size class had standing water less frequently and for shorter durations during the four-year period compared to the three other size classes, particularly the largest size class (fig. 5). Playas in the smallest size class had dry conditions in more than $85 \%$ of observations for each year (table 6), and standing water observations exceeded $10 \%$ for only 13 months of the four-year period. Playas in the largest size class had the lowest percentage of dry observations every year (table 6), and standing water observations exceeded 10\% for 22 months. Greater than $90 \%$ of small playas were on average dry for the four-year period, and when they did store water it was for short periods. Conversely, at least some playas in the largest size class typically had standing water and only twice were all large playas dry in consecutive months.

Results from ANOVA indicate there are significant differences in water status by playa size class (table 7). Differences are significant in percentage of standing water observations in 2016, 2019, and the four-year mean. Tukey's HSD indicates significant differences between the two smallest size classes and the two largest size class. Playas in the two smallest size classes had the greatest percentage of dry playas for 31 of the 48-month study period, while playas in the two largest size classes had the greatest percentage of dry playas in only seven months.

Water status also exhibits similar seasonal trends by watershed size class (fig. 6). Playas in the smallest watershed size class had the lowest percentage of standing water observations for every year of observation, and playas in the largest watershed size class consistently had the highest percentage of standing water observations (table 6). Differences in percentage of standing water observations are significant in 2017, 2019, and the fouryear mean (table 7). Tukey's HSD indicates significant differences occur between playas in the largest watershed size class and the three other size classes.

Playa surface area and watershed area are significantly positively correlated with percent standing water observations in 2016, 2017, 2019, and the fouryear mean (table 8 ). Playa and watershed circularity are not significantly correlated with percent standing 
water observations for any year or the fouryear mean. Watershed mean slope is only significantly correlated (positive) with percent standing water observations in 2016.

Playa area is not significantly correlated with watershed circularity, watershed mean slope, or watershed mean tilled index, so all three variables were entered into a regression analysis stepwise to evaluate the role of these variables in explaining variability in playa water status. However, only playa area met the probability criteria of $\mathrm{F}<0.05$ to remain in the regression analysis. Results indicate that playa area explains about $20 \%$ of the variance in playa water status $\left(r^{2}=0.205\right.$, root mean square error $[$ RMSE] $=7.67$ ). Due to a high degree of correlation with playa area, regression analysis with watershed area was conducted separately. Watershed area is not significantly correlated with playa circularity, watershed circularity, watershed mean slope, or watershed tilled index, so these variables were entered into a regression analysis stepwise to evaluate the role of these variables in explaining variability in playa water status. Only watershed area met the probability criteria of $\mathrm{F}<0.05$ to remain in the regression analysis, and results indicate watershed area explains about $15 \%$ of the variance in playa water status $\left(r^{2}=0.148\right.$, RMSE $=7.94$ ). Thus, playa and watershed circularity and watershed slope do not exert a significant influence on playa water status, while playa area is a stronger predictor of playa water status than watershed area.

Seasonal trends in water status are similar over time among TI classes (fig. 7). In 2016 and 2017, grassland playas had slightly greater percentages of standing water observations, and cropland playas had slightly greater percentages in 2018, 2019, and the four-year mean (table 6). Mixed playas consistently had the lowest percentage of standing water observations among the three TI classes. Although seasonal to annual trends are similar by TI class, there are monthly differences in playa water status. During the four-year study period, playas in cropland watersheds had only seven months when there were no standing water observations. Playas in

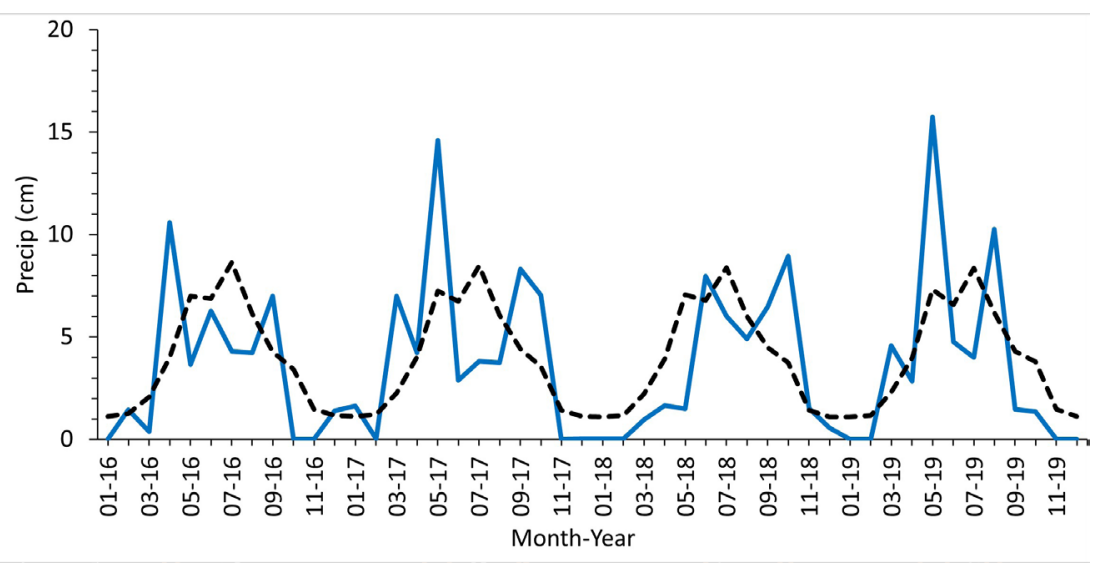

Figure 3. Precipitation at Oakley 22S High Plains Regional Climate Center weather station $\left(38.7853^{\circ},-100.874^{\circ}\right)$ in Logan County, Kansas, for the years 2016-2019 (blue line) and a 28- to 30-year moving average (black dashed line).

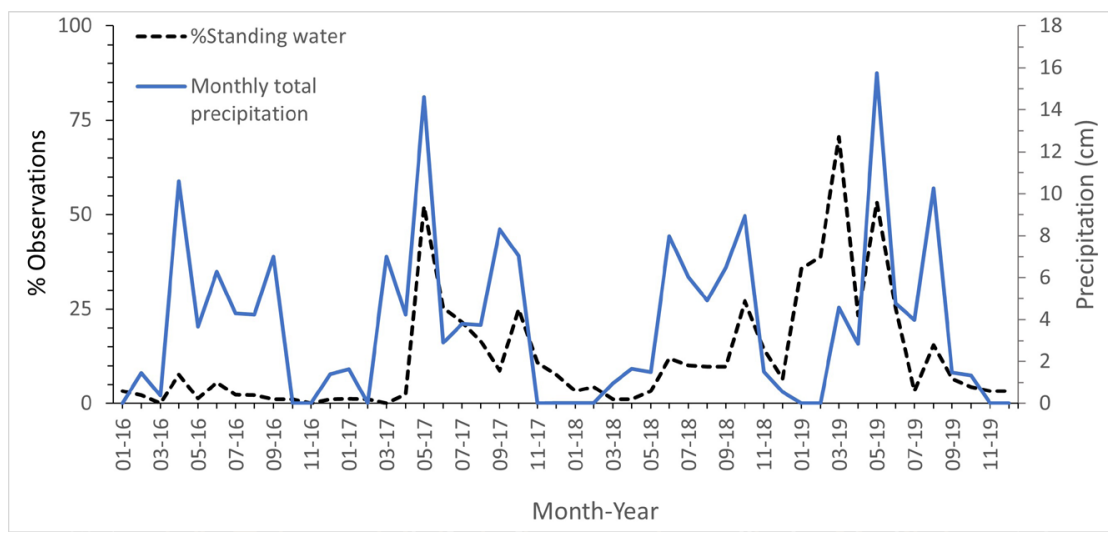

Figure 4. Percentage of playa water status observations as standing water on PlanetScope monthly mosaic satellite imagery for 92 playas distributed throughout western Kansas (dashed black line) and monthly precipitation (blue line) at Oakley 22S High Plains Regional Climate Center weather station for the years 2016-2019.

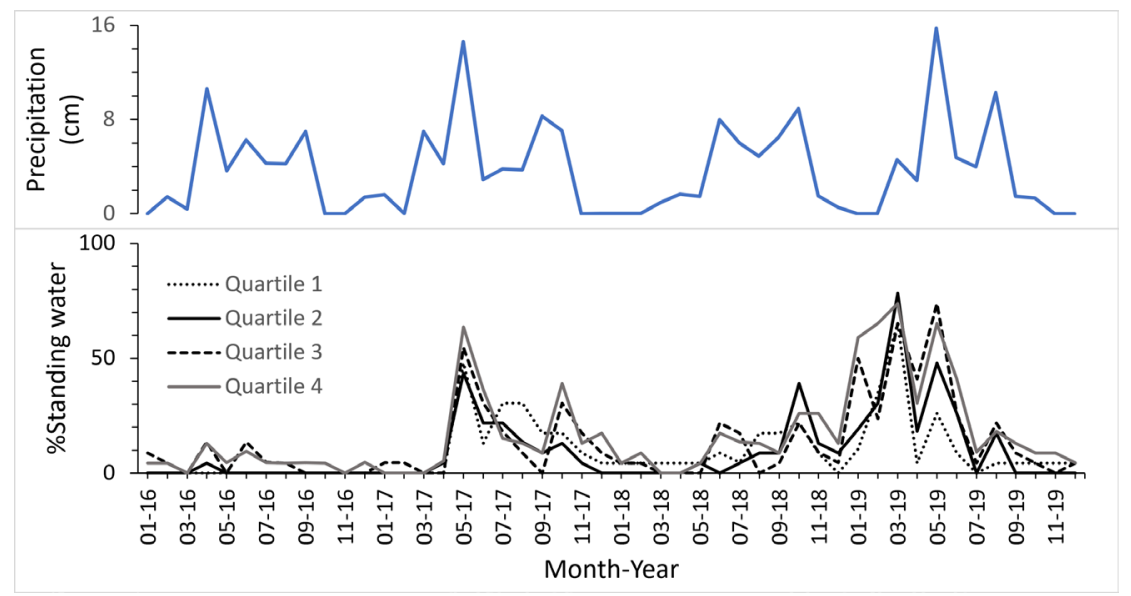

Figure 5. Precipitation recorded at Oakley 22S High Plains Regional Climate Center weather station (blue line) and percentage of playa water status observations as standing water on PlanetScope monthly mosaic satellite imagery for 92 playas distributed throughout western Kansas categorized by playa surface area quartile size class (quartile $1=$ dotted line; quartile 2 = solid black line; quartile 3 = dashed black line; quartile 4 = gray line) for the years 2016-2019. 
Table 6. Summary of playa water status observations (i.e., percent dry or standing water) from 2016 to 2019 and the four-year mean for all 92 playas by playa surface area quartile size class, watershed area size class, and watershed tilled index class (i.e., cropland, grassland, and mixed).

\begin{tabular}{|c|c|c|c|c|c|c|}
\hline & & 2016 & 2017 & 2018 & 2019 & Mean \\
\hline \multirow[t]{2}{*}{ All sites ( $n=92$ ) } & $\%$ Dry & 97.7 & 85.5 & 91.4 & 76.5 & 87.8 \\
\hline & \%Standing water & 2.3 & 14.5 & 8.6 & 23.5 & 12.2 \\
\hline \multicolumn{7}{|c|}{ Playa Size Class } \\
\hline \multirow[t]{2}{*}{ Quartile $1(n=23)$} & \%Dry & 100.0 & 85.9 & 91.6 & 85.7 & 90.8 \\
\hline & \%Standing water & 0.0 & 14.1 & 8.4 & 14.3 & 9.2 \\
\hline \multirow[t]{2}{*}{ Quartile 2 ( $n=23$ ) } & \%Dry & 99.6 & 89.1 & 92.8 & 80.2 & 90.4 \\
\hline & \%Standing water & 0.4 & 10.9 & 7.2 & 19.8 & 9.6 \\
\hline \multirow[t]{2}{*}{ Quartile $3(n=23)$} & \%Dry & 95.9 & 85.2 & 92.7 & 73.0 & 86.7 \\
\hline & \%Standing water & 4.1 & 14.8 & 7.3 & 27.0 & 13.3 \\
\hline \multirow[t]{2}{*}{ Quartile 4 (n=23) } & \%Dry & 95.1 & 82.4 & 88.7 & 66.9 & 83.3 \\
\hline & \%Standing water & 4.9 & 17.6 & 11.3 & 33.1 & 16.7 \\
\hline \multicolumn{7}{|c|}{ Watershed Size Class } \\
\hline \multirow[t]{2}{*}{ Quartile $1(n=23)$} & \%Dry & 100.0 & 88.7 & 93.8 & 85.8 & 92.1 \\
\hline & \%Standing water & 0.0 & 11.3 & 6.2 & 14.2 & 7.9 \\
\hline \multirow[t]{2}{*}{ Quartile 2 ( $n=23)$} & \%Dry & 96.7 & 87.2 & 93.0 & 75.7 & 88.2 \\
\hline & \%Standing water & 3.3 & 12.8 & 7.0 & 24.3 & 11.8 \\
\hline \multirow[t]{2}{*}{ Quartile $3(n=23)$} & $\%$ Dry & 98.9 & 88.5 & 90.9 & 78.8 & 89.3 \\
\hline & \%Standing water & 1.1 & 11.5 & 9.1 & 21.2 & 10.7 \\
\hline \multirow[t]{2}{*}{ Quartile 4 (n=23) } & \%Dry & 95.2 & 78.1 & 88.0 & 65.7 & 81.7 \\
\hline & \%Standing water & 4.8 & 21.9 & 12.0 & 34.3 & 18.3 \\
\hline \multicolumn{7}{|c|}{ Tilled Index Class } \\
\hline \multirow[t]{2}{*}{ Cropland $(n=54)$} & \%Dry & 98.0 & 85.3 & 89.0 & 74.6 & 86.7 \\
\hline & \%Standing water & 2.0 & 14.7 & 11.0 & 25.4 & 13.3 \\
\hline \multirow[t]{2}{*}{ Grassland $(n=24)$} & \%Dry & 96.7 & 84.6 & 94.8 & 77.0 & 88.3 \\
\hline & \%Standing water & 3.3 & 15.4 & 5.2 & 23.0 & 11.7 \\
\hline \multirow{2}{*}{$\begin{array}{l}\text { Mixed } \\
(\mathrm{n}=14)\end{array}$} & \%Dry & 98.2 & 88.7 & 95.2 & 82.2 & 91.1 \\
\hline & \%Standing water & 1.8 & 11.3 & 4.8 & 17.8 & 8.9 \\
\hline
\end{tabular}

grassland watersheds experienced 18 months with no standing water observations, and playas in the mixed TI class had 27 months with no standing water observations. Cropland playas had the highest percentage of standing water observations for 25 months, while grassland playas had the highest percentage for 14 months and mixed playas for 5 months. However, results from ANOVA indicate that differences in water status were not significant by TI class (table 7). Thus, watershed land cover does not explain significant variance in playa water status $\left(\mathrm{r}^{2}=0.006\right.$, RMSE $=8.57$ ).
Playa water status generally responds to seasonal shifts in precipitation patterns, regardless of size class or TI class (figs. 5-7). Percentage of standing water observations were generally highest in late spring to early summer, periods of maximum precipitation, with secondary peaks during late fall to winter. In 2016, average standing water observations for all 92 playas increased from $0 \%$ in March to $7.7 \%$ in April after the area received $10.6 \mathrm{~cm}$ of rainfall. This response was seen across TI classes, though response in grassland and mixed playas was slightly greater than cropland playas. This response also occurred across playa 
Table 7. Results of one-way ANOVA comparing mean differences in percentage of standing water observations in playas for each year from 2016 to 2019 and the four-year mean by watershed tilled index class (i.e., cropland, grassland, and mixed), playa surface area quartile size class, and watershed area quartile size class. Bold numbers are significant at $p<0.05$; bold and italic numbers are significant at $p<0.01$.

\begin{tabular}{lccccccc}
\hline & \multicolumn{2}{c}{ Playa Size Class } & \multicolumn{2}{c}{ Watershed Size Class } & \multicolumn{2}{c}{ Tilled Index Class } \\
\hline \%Standing water observations & F value & P value & F value & P value & \multicolumn{1}{c}{ F value } & P value \\
\hline 2016 & $\mathbf{3 . 5 2 4}$ & $\mathbf{0 . 0 1 8}$ & 2.490 & 0.066 & 0.287 & 0.751 \\
2017 & 1.963 & 0.125 & $\mathbf{3 . 7 2 3}$ & $\mathbf{0 . 0 1 4}$ & 0.421 & 0.658 \\
2018 & 0.472 & 0.702 & 1.066 & 0.368 & 2.761 & 0.069 \\
2019 & $\mathbf{9 . 5 3 6}$ & $\mathbf{0 . 0 0 0}$ & $\mathbf{6 . 5 7 3}$ & $\mathbf{0 . 0 0 0}$ & 1.236 & 0.296 \\
4-year mean & $\mathbf{6 . 7 5 4}$ & $\mathbf{0 . 0 0 0}$ & $\mathbf{7 . 1 5 0}$ & $\mathbf{0 . 0 0 0}$ & 1.580 & 0.212 \\
\hline
\end{tabular}

Table 8. Bivariate correlation matrix of percentage of standing water observations in playas for each year from 2016 to 2019 and the four-year mean and playa and watershed morphometric variables. Bold numbers are significant at $p<0.05$; bold and italic numbers are significant at $p<0.01$.

\begin{tabular}{|c|c|c|c|c|c|c|}
\hline $\begin{array}{l}\text { \%Standing we } \\
\text { observation }\end{array}$ & & Playa Area & Playa Circularity & Watershed Area & $\begin{array}{l}\text { Watershed } \\
\text { Circularity }\end{array}$ & $\begin{array}{l}\text { Watershed } \\
\text { Mean Slope }\end{array}$ \\
\hline \multirow{2}{*}{2016} & r & 0.227 & -0.133 & 0.227 & -0.006 & 0.300 \\
\hline & $P$ & 0.030 & 0.207 & 0.029 & 0.953 & 0.004 \\
\hline \multirow{2}{*}{2017} & $r$ & 0.255 & 0.025 & 0.287 & -0.005 & -0.051 \\
\hline & $\mathrm{P}$ & 0.014 & 0.815 & 0.006 & 0.964 & 0.627 \\
\hline \multirow{2}{*}{2018} & $r$ & 0.160 & 0.204 & 0.202 & -0.096 & 0.004 \\
\hline & $P$ & 0.127 & 0.051 & 0.053 & 0.363 & 0.973 \\
\hline \multirow{2}{*}{2019} & r & 0.513 & -0.041 & 0.327 & -0.007 & -0.061 \\
\hline & $P$ & 0.000 & 0.696 & 0.001 & 0.950 & 0.561 \\
\hline \multirow{2}{*}{ 4-year mean } & $r$ & 0.452 & 0.038 & 0.385 & -0.039 & 0.013 \\
\hline & P & 0.000 & 0.716 & 0.000 & 0.710 & 0.902 \\
\hline
\end{tabular}

and watershed size classes except for the smallest playa size class, which remained at $0 \%$ standing water for every month of 2016. Percentage of standing water observations increased dramatically from 2.4\% in April 2017 to 52.2\% in May; the study area received $14.6 \mathrm{~cm}$ of precipitation during that time. The largest playa and watershed size classes and grassland TI class exhibited the greatest increases. From late fall 2017 to spring 2018, the region received only $4.2 \mathrm{~cm}$ of rainfall. Percentage of standing water observations steadily declined until $8 \mathrm{~cm}$ of rainfall was received in June 2018; the percentage of standing water observations increased to $12 \%$ and remained at $10 \%$ or greater through November as the region received 35.8 cm of precipitation. From October 2018 to March 2019, the region received $98 \mathrm{~cm}$ of snowfall, and snow was visible on satellite imagery throughout the study area for most months during this period. The percentage of standing water observations increased considerably and reached the four-year maximum of 70.7\% in March 2019 with a combination of $4.6 \mathrm{~cm}$ of rainfall and snowmelt. Even though the region received $37.6 \mathrm{~cm}$ of rainfall from April to August 2019, the percentage of standing water observations decreased from the four-year high of $70.7 \%$ in March to 3.3\% in July and remained at or below 15\% for the remainder of 2019. Regression analysis indicates that monthly precipitation explains about $20 \%$ of the variability in playa water status $\left(r^{2}=0.205\right.$, RMSE $\left.=14.13\right)$. Percentage of standing water observations is not related to previous monthly rainfall $\left(\mathrm{r}^{2}=0.011\right.$, RMSE $\left.=15.75\right)$, and monthly rainfall plus previous monthly rainfall decreases the relationship with percentage of standing water observations $\left(r^{2}=0.131\right.$, RMSE $\left.=14.77\right)$.

Thus, playa water status is in part explained by playa area, watershed area, and precipitation patterns but 
not watershed land cover or previous monthly rainfall. Playa area and watershed area are significantly positively correlated, and playa area versus percent standing water observations has a higher $\mathrm{r}^{2}$ value and lower RMSE, suggesting the size of the playa has a stronger control on playa water status than watershed area. Precipitation versus percentage of standing water observations has an equivalent $\mathrm{r}^{2}$ value as playa area, though RMSE is higher.

\section{DISCUSSION}

Playa and Watershed Morphology and Playa Water Status hydroperiod. Tsai et al. (2007) examined the influence of playa size on hydroperiod and water loss rate from June to September for playas on the Southern High Plains. Their results indicate that playa area was not an important factor influencing playa hydroperiod or water loss rate. However, their study only included playas that were currently storing water during site selection and for a single season, so they did not examine the effect of playa area on a playa becoming inundated and storing water over a prolonged period. Johnson et al. (2011) evaluated and modeled several factors that

Because of the wide range in monthly playa water status among all sites over the four-year period, playa and watershed morphology are not consistently significantly correlated with playa water status. Playa area and watershed area are the only morphometric variables significantly correlated with standing water observations for more than one year; both are significantly positively correlated with percentage of standing water observations for three of the four years of observation and the four-year mean. This indicates that on average, larger playas and playas in larger watersheds store water more frequently. Playas only receive water inputs from runoff and direct precipitation (Smith, 2003), and as watershed area increases, the amount of runoff generated increases (Knighton, 2014). Larger playas have a greater capacity to store water, and larger watersheds capture more precipitation and contribute more runoff to the playa.

Playa and watershed circularity are not significantly correlated with playa water status for any year of observation even though rounder watersheds typically contribute more runoff than elongate watersheds (Strahler, 1957; Syed et al., 2003). Additionally, watershed mean slope is only significantly correlated with playa water status in 2016, even though steeper slopes generate more runoff (Strahler, 1957). Lack of significant correlation of circularity and slope with playa water status may be due to the limited range in circularity and slope among research sites.

The influence of playa size on hydroperiod has had conflicting results in previous studies; no known studies examine the influence of watershed size on playa

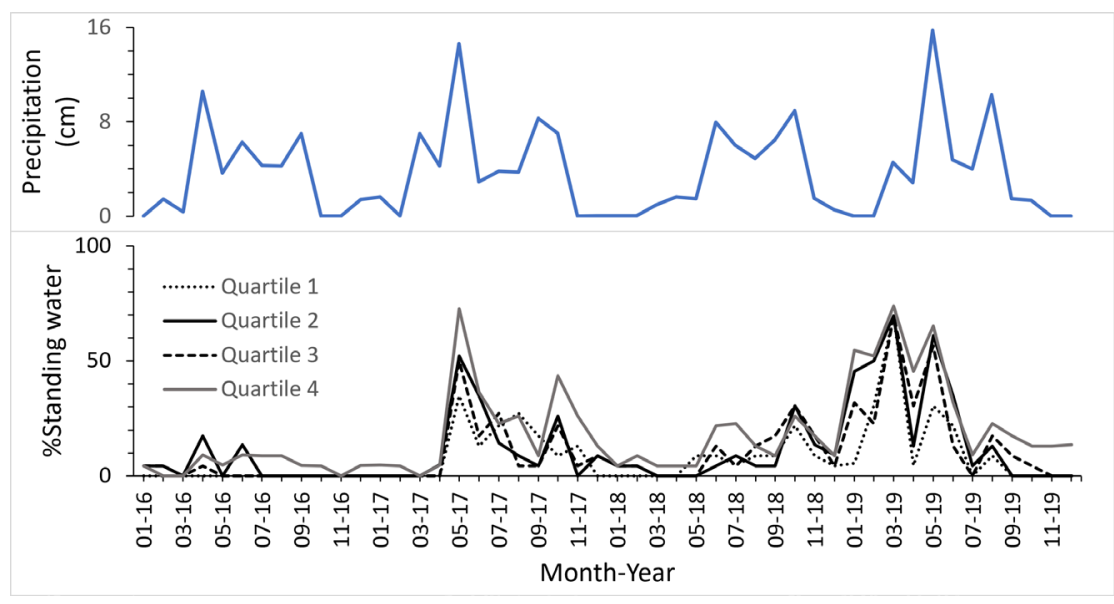

Figure 6. Precipitation recorded at Oakley 22S High Plains Regional Climate Center weather station (blue line) and percentage of playa water status observations as standing water on PlanetScope monthly mosaic satellite imagery for 92 playas distributed throughout western Kansas categorized by watershed area quartile size class (quartile 1 = dotted line; quartile 2 = solid black line; quartile 3 = dashed black line; quartile 4 = gray line) for the years 2016-2019.

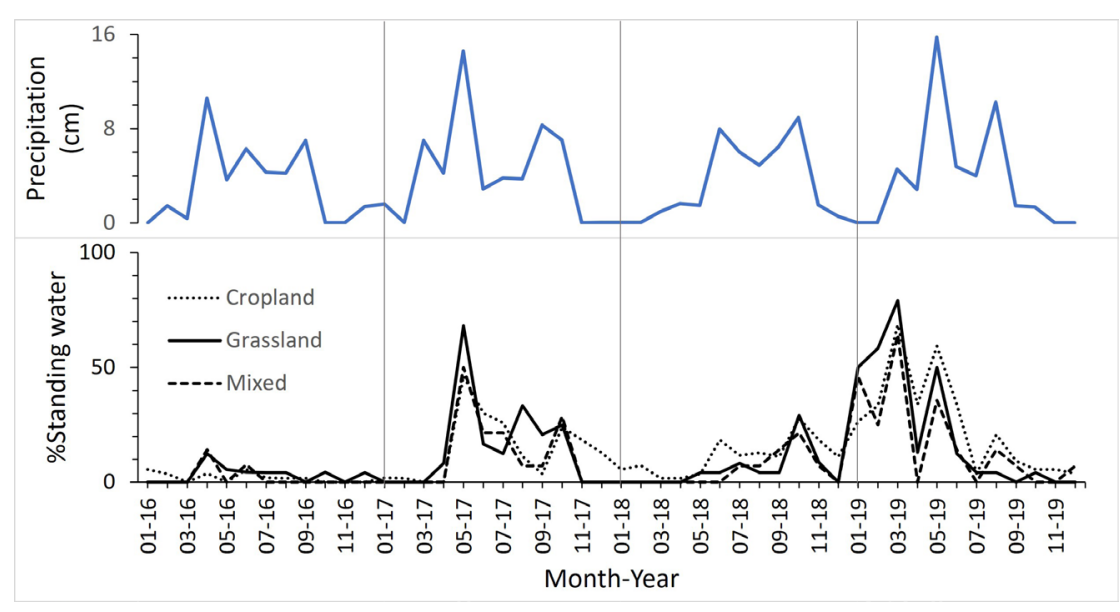

Figure 7. Precipitation recorded at Oakley 22S High Plains Regional Climate Center weather station (blue line) and percentage of playa water status observations as standing water on PlanetScope monthly mosaic satellite imagery for 92 playas distributed throughout western Kansas categorized by cropland (dotted line), grassland (solid line), and mixed (dashed line) tilled index classes for the years 2016-2019. 
influence playa inundation for playas on the Texas High Plains. They found that playa area was positively related to probability of inundation, but the most influential variables were percent grassland in the watershed, average annual rainfall, and previous year's rainfall. In southwestern Nebraska, playa size was positively related to probability of inundation, and probability of inundation increased by $15 \%$ for every hectare increase in playa size (Cariveau et al., 2011). However, amount of precipitation and surrounding land cover were more influential on playa inundation. As such, while playa and watershed morphology have an influence on playa water status, this study and previous studies indicate that they are not strong predictors of playa water status.

\section{Watershed Land Cover and Playa Water Status}

Watershed land cover for sites included in this study ranged from $100 \%$ cropland to $100 \%$ grassland. Sites were biased toward cropland, with 54 of the 92 playas (about $59 \%$ ) within the cropland TI class. This is not surprising given that for the counties included in this study, percent land in farms ranged from $76.2 \%$ to $100 \%$ and percent harvested cropland ranged from 31\% to 56\% in 2017 (table 1) (Kansas Department of Agriculture, 2019). Playas in the three TI classes were distributed across the study area and across the range of playa and watershed sizes. Each county in the study area included playas in all three TI classes, except for Logan/Gove counties. The Smoky Hill River and several tributaries, which are deeply incised, flow through Logan/Gove counties, and playas and cropland are concentrated on the small patches of flatter uplands.

Previous research indicates cropland-dominated watersheds deliver more runoff to playas (Tsai et al., 2007), while increased grassland within watersheds, particularly Conservation Reserve Program (CRP) grasses, reduces runoff and water delivery to playas (Bartuszevige et al., 2012; Cariveau et al., 2011). Thus, for a given rain event, cropland playas are likely to receive more water than grassland playas. Conversely, Zhang et al. (2020) examined spring water ponding status for playas in the Rainwater Basin of Nebraska from 2004 to 2015 and found that playas enrolled in a conservation program (e.g., waterfowl production areas, wildlife management areas, and wetland reserve program easements) are more likely to be ponded and have a greater ponded area than non-conservation program playas. However, the study focused only on land cover within and immediately adjacent to playas, and previous research on playas in the study area indicates watersheds, including about $90 \%$ of playas, are dominated by cultivated cropland (Daniel et al., 2015).

Playa water loss rate is positively correlated with watershed tilled index (i.e., as the percentage of cropland area increases, playas store water for shorter periods) (Tsai et al., 2007), and probability of playa inundation is positively correlated with proportion of grassland in the watershed for playas on the Southern High Plains (Johnson et al., 2011). Decreased water storage and probability of inundation within cropland playas even though they receive more runoff is attributed to greater accumulation of stored sediment within playas as a result of increased erosion from cropland (Johnson et al., 2011; Tsai et al., 2007). As amount of sediment stored within a playa increases, surface area increases relative to depth, enhancing evaporation, and water spreads onto more permeable soils, increasing infiltration (Luo et al., 1997; Tsai et al., 2007).

Cropland playas in Kansas have accumulated much less sediment and have lost a much smaller percentage of playa storage volume (Bowen and Johnson, 2019, 2017) compared to cropland playas on the Southern High Plains (Daniel et al., 2014; Johnson et al., 2012; Luo et al., 1997), which is due in part to differences in site selection processes, different criteria for identifying sediment, and heterogeneity of landscapes (i.e., climate, soils, topography, land cover, crop types, agriculture practices) across such a broad region. Thus, cropland playas included in this study likely still have sufficient water storage capacity to retain standing water for longer periods if they receive greater runoff than grassland playas. However, there are no statistically significant differences in playa water status by TI class for any year of observation. Lack of significant differences may be due to a much greater number of cropland playas $(n=54)$ included in this study compared to grassland ( $\mathrm{n}=24)$ and mixed $(\mathrm{n}=14)$ playas. Additionally, this study documented only absence/ presence of standing water in playas; it did not measure area of playa inundated with water. Further research and a more robust dataset are necessary to determine whether cropland playas receive enhanced runoff and store water for significantly longer periods compared to grassland playas.

It was not possible to differentiate native grassland from CRP grassland, which significantly reduces water delivery to playas (Bartuszevige et al., 2012; Cariveau et al., 2011), and it is likely that several playas within the grassland cover class had at least a portion of the watershed enrolled in CRP. Interestingly, during the much drier than average 2016, grassland playas had a higher 
percentage of standing water observations than cropland and mixed playas, suggesting the effects of droughts may be more severe for cropland playas. Research over a longer period with a greater number of grassland playas would be necessary to test this hypothesis.

\section{Precipitation and Playa Water Status}

Percentage of standing water observations is related to monthly precipitation total. Distinct peaks in precipitation coincide with peaks in percentage of standing water observations. Monthly average percentage of standing water observations is significantly positively correlated with monthly precipitation for all 92 sites, all four playa size classes, all four watershed size classes, and all three TI classes (table 9). Including the previous month's rainfall reduces the relationship between standing water in playas and precipitation. This suggests playa water storage is in response to single event or shortterm (i.e., monthly) precipitation patterns. Playas in the two smallest playa and watershed size classes are more sensitive to seasonal and longer droughts, with several consecutive months of $100 \%$ dry observations during prolonged dry periods.

\section{Human Activities and Playa Water Status}

Human activities and alterations of the landscape also have had profound effects on playas, including water status (Smith, 2003). Common human activities that negatively impact playa water status include construction of drainage ditches, pits on playa floors, agricultural terraces, water diversions, and roads; overgrazing; land leveling; urbanization; and cultivation of the playa and watershed (Bowen and Johnson, 2017; Johnson et al., 2012; Smith et al., 2011). Other human activities — such as dredging of sediments to increase playa volume (Daniel et al., 2015), enrolling playas in conservation programs (Tang et al., 2016; Zhang et al., 2020), and enhancing water delivery to playas through irrigation (Tsai et al., 2007) can positively affect playa water status.

For this study, sites were selected to intentionally avoid playas with visible signs of human alterations other than cultivation. However, watersheds associated with this study's sites exhibited a variety of human alterations, including roads, ditches, terraces, land enrolled in conservation programs, and irrigation. By examining aerial images, it was determined that 15 of the 54 cropland playas had center pivot irrigation within their watersheds, but no grassland playas had center pivot irrigation within their watersheds. Only two playas with
Table 9. Bivariate correlation of monthly precipitation and monthly average percent standing water observations from 2016 to 2019 for all 92 playas by playa surface area quartile size class, watershed area quartile size class, and tilled index class (i.e., cropland, grassland, and mixed). Bold and italic numbers are significant at $p<0.01$.

\begin{tabular}{|c|c|c|}
\hline & \multicolumn{2}{|c|}{ \%Standing Water } \\
\hline \multirow[t]{2}{*}{ All playas } & r & 0.453 \\
\hline & $\mathrm{P}$ & 0.001 \\
\hline \multicolumn{3}{|c|}{ Playa size class } \\
\hline \multirow[t]{2}{*}{ Quartile 1} & r & 0.376 \\
\hline & $\mathrm{P}$ & 0.009 \\
\hline \multirow[t]{2}{*}{ Quartile 2} & $r$ & 0.456 \\
\hline & $\mathrm{P}$ & 0.001 \\
\hline \multirow[t]{2}{*}{ Quartile 3} & r & 0.491 \\
\hline & $\mathrm{P}$ & 0.000 \\
\hline \multirow[t]{2}{*}{ Quartile 4} & r & 0.379 \\
\hline & $\mathrm{P}$ & 0.008 \\
\hline \multicolumn{3}{|c|}{ Watershed size class } \\
\hline \multirow[t]{2}{*}{ Quartile 1} & $r$ & 0.389 \\
\hline & $\mathrm{P}$ & 0.006 \\
\hline \multirow[t]{2}{*}{ Quartile 2} & r & 0.438 \\
\hline & $\mathrm{P}$ & 0.002 \\
\hline \multirow[t]{2}{*}{ Quartile 3} & r & 0.484 \\
\hline & $\mathrm{P}$ & 0.000 \\
\hline \multirow[t]{2}{*}{ Quartile 4} & r & 0.414 \\
\hline & $\mathrm{P}$ & 0.003 \\
\hline \multicolumn{3}{|c|}{ Tilled index class } \\
\hline \multirow[t]{2}{*}{ Cropland } & r & 0.436 \\
\hline & $\mathrm{P}$ & 0.002 \\
\hline \multirow[t]{2}{*}{ Grassland } & r & 0.418 \\
\hline & $\mathrm{P}$ & 0.003 \\
\hline \multirow[t]{2}{*}{ Mixed } & r & 0.453 \\
\hline & $\mathrm{P}$ & 0.001 \\
\hline
\end{tabular}

irrigation in their watershed had a higher percentage of standing water observations compared to playas without irrigation within the same county. Thus, the effects of irrigation throughout the study area are negligible but may be significant for individual playas. No other effects of human alterations on playa water status beyond conversion of playas and watersheds to cropland were quantified for this study. 


\section{CONCLUSIONS}

Controls on a playa's ability to store water are complicated and include playa and watershed area, watershed land cover, and precipitation patterns. Playa and watershed area are positively correlated, and as playa area increases, watershed area and the ability to store water increases. Playa water status was not correlated with playa or watershed circularity or watershed mean slope. Playas in cropland watersheds store water more frequently and for longer periods than playas in grassland watersheds, though differences are not statistically significant. Standing water within playas is positively correlated with monthly precipitation and reflects a short-term response to precipitation patterns, regardless of playa size or watershed land cover. There are no statistically significant differences in annual standing water observations among TI classes and only two of the four years exhibit significant differences by playa and watershed size class. The strongest controls on playa water status are playa area, monthly precipitation, and watershed area. Human activities beyond altering playa and watershed land cover also likely influence playa water status, but only the effects of conversion to cropland and presence of irrigation in the watershed on playa water status were assessed for this study.

Further research is required to better understand the spatial and temporal variability in playa water status driven by precipitation patterns. The High Plains Regional Climate Center includes more than 100 weather stations distributed throughout western Kansas, with continuous temperature and precipitation records for some stations exceeding 100 years. A more robust dataset, with playas and weather stations distributed throughout the entire High Plains region of Kansas and equally distributed by TI class, would provide further insight into the relative influence of the timing and duration of precipitation versus land cover on playa water status. Additionally, for this study, outliers were removed based on playa and watershed morphology. Thus, most "large" playas and watersheds were removed from the dataset, and this study focused on a relatively narrow range of playa and watershed sizes. If these much larger playas and watersheds had not been removed, the influence of playa and watershed area on playa water status may have been more dramatic.

Furthermore, incorporating records that extend further into the past could reveal the effects of climate change on playa water status. The primary limitation to extending the analysis further is lack of high temporal resolution data on playa water status prior to 2016 at sufficient spatial resolution to include smaller playas. Climate change scenarios with predicted increased frequency of high intensity storm events could result in playas storing water more frequently. However, increased runoff leading to increased sediment accumulation within playas would decrease playa water storage capacity, and coupled with predicted temperature increases, could result in significant declines in playa water storage.

Playas are critical resources for the High Plains, providing a range of ecosystem services that are dependent upon the playa's ability to store water. Playa functions are under continued threat from cropland expansion, climate change, and playa and watershed modifications. To reduce groundwater decline and maintain or improve regional biodiversity, it is essential that playas continue to receive and store surface water inputs. Playas in cropland watersheds receive and store more sediment than grassland playas (Bowen and Johnson, 2017; Luo et al., 1997), which depletes playa water storage volume and may ultimately lead to increased water loss rates. To sustain playa functions in Kansas, efforts should focus on conserving larger grassland playas and reducing sediment inputs to playas in cropland watersheds.

\section{ACKNOWLEDGMENTS}

Thank you to Dr. Fei Yuan (Department of Geography) and Dr. Ryan Wersal (Department of Biological Sciences) at Minnesota State University, Mankato and three anonymous reviewers for providing constructive reviews that greatly improved this manuscript.

\section{REFERENCES}

Barbato, G., Barini, E., Genta, G., and Levi, R., 2011, Features and performance of some outlier detection methods: Journal of Applied Statistics, v. 38, p. 2,133-2,149.

Bartuszevige, A. M., Pavlacky D. C., Jr., Burris, L., and Herbener, K., 2012, Inundation of playa wetlands in the western Great Plains relative to land cover context: Wetlands, v. 32, p. 1,103-1,113.

Bowen, M. W., and Johnson, W. C., 2017, Anthropogenically accelerated sediment accumulation within playa wetlands as a result of land cover change on the High Plains of the central United States: Geomorphology, v. 294, p. 135-145.

Bowen, M. W., and Johnson, W. C., 2019, Sediment accumulation and sedimentation rates in playas on the High Plains of western Kansas, USA: Geomorphology, v. 342, p. 117-126.

Bowen, M. W., Johnson, W. C., Egbert, S. L., and Klopfenstein, S. T., 2010, A GIS-based approach to identify and map playa wetlands on the High Plains, Kansas, USA: Wetlands, v. 30, p. 675-684. 
Buchanan, R. C., Wilson, B. B., Buddemeier, R. R., and Butler, J. J. Jr., 2015, The High Plains aquifer: Kansas Geological Survey, Public Information Circular 18, 6 p.

Cariveau, A. B., Pavlacky, D. C., Bishop, A. A., and LaGrange, T. G., 2011, Effects of surrounding land use on playa inundation following intense rainfall: Wetlands, v. 31, p. 65-73.

Daniel, D. W., Smith, L. M., Haukos, D. A., Johnson, L. A., and McMurry, S. T., 2014, Land use and conservation reserve program effects on the persistence of playa wetlands in the High Plains: Environmental Science \& Technology, v. 48, p. 4,282-4,288.

Daniel, D. W., Smith, L. M., and McMurry, S. T., 2015, Land use effects on sedimentation and water storage volume in playas of the rainwater basin of Nebraska: Land Use Policy, v. 42, p. 426-431.

Dennehy, K., Litke, D., and McMahon, P., 2002, The High Plains aquifer, USA: Groundwater development and sustainability: Geological Society, London, Special Publications 193, p. 99-119.

Easterling, D. R., Kunkel, K., Arnold, J., Knutson, T., LeGrande, A., Leung, L. R., Vose, R., Waliser, D., and Wehner, M., 2017, Precipitation change in the United States; in Climate Science Special Report: Fourth National Climate Assessment, Volume I: U.S. Global Change Research Program, Washington, D.C., p. 207-230.

Gunter, J., Hurd, G. M., Wedel, X., and Byrd, A., 2019, Kansas Statistical Abstract 2018: University of Kansas Institute for Policy \& Social Research, 574 p. https: / / kuscholarworks. ku.edu/handle/1808/29611

Gurdak, J. J., and Roe, C. D., 2010, Review: Recharge rates and chemistry beneath playas of the High Plains aquifer, USA: Hydrogeology Journal, v. 18, p. 1,747-1,772.

Hartman, M. D., Merchant, E. R., Parton, W. J., Gutmann, M. P., Lutz, S. M., and Williams, S. A., 2011, Impact of historical land-use changes on greenhouse gas exchange in the US Great Plains, 1883-2003: Ecological Applications, v. 21, p. 1,105-1,119.

High Plains Regional Climate Center, 2020, http: / / www.hprcc. unl.edu.

Hoaglin, D. C., Iglewicz, B., and Tukey, J. W., 1986, Performance of some resistant rules for outlier labeling: Journal of the American Statistical Association, v. 81, p. 991-999.

Johnson, L. A., Haukos, D. A., Smith, L. M., and McMurry, S. T., 2012, Physical loss and modification of Southern Great Plains playas: Journal of Environmental Management, v. 112, p. 275-283.

Johnson, W. P., Rice, M. B., Haukos, D. A., and Thorpe, P. P., 2011, Factors influencing the occurrence of inundated playa wetlands during winter on the Texas High Plains: Wetlands, v. 31, p. 1,287-1,296.

Kansas Department of Agriculture, 2019, Kansas Farm Facts: http: / / agriculture.ks.gov/ about-ksda/kansas-agriculture.

Knighton, D., 2014, Fluvial Forms and Processes: A New Perspective: New York, Routledge, 383 p.

Kuchler, A. W., 1974, A new vegetation map of Kansas: Ecology, v. 55, p. 586-604.

Kustu, M. D., Fan, Y., and Robock, A., 2010, Large-scale water cycle perturbation due to irrigation pumping in the US High
Plains: A synthesis of observed streamflow changes: Journal of Hydrology, v. 390, p. 222-244.

Lark, T. J., Salmon, J. M., and Gibbs, H. K., 2015, Cropland expansion outpaces agricultural and biofuel policies in the United States: Environmental Research Letters 10, 044003.

Luo, H.-R., Smith, L. M., Allen, B. L., and Haukos, D. A., 1997, Effects of sedimentation on playa wetland volume: Ecological Applications, v. 7, p. 247-252.

McGuire, V. L., 2017, Water-level and recoverable water in storage changes, High Plains aquifer, predevelopment to 2015 and 2013-15 (Scientific Investigations Report No. 2017-5040): US Geological Survey, 14 p.

Miller, V. C., 1953, A quantitative geomorphic study of drainage basin characteristics in the Clink Mountain area Virginia and Tennessee (Technical Report No. 3): Columbia University Department of Geology, New York.

Peel, M. C., Finlayson, B. L., and McMahon, T. A., 2007, Updated world map of the Köppen-Geiger climate classification: Hydrology and Earth System Sciences Discussions, v. 4, p. 439-473.

Sabin, T. J., and Holliday, V. T., 1995, Playas and lunettes on the southern High Plains: Morphometric and spatial relationships: Annals of the Association of American Geographers, v. 85, p. 286-305.

Shafer, M., Ojima, D., Antle, J., Kluck, D., McPherson, R., Petersen, S., Scanlon, B., and Sherman, K., 2014, Chapter 19: Great Plains; in Climate Change Impacts in the United States: The Third National Climate Assessment: U.S. Global Change Research Program, p. 441-461.

Smith, L. M., 2003, Playas of the Great Plains: University of Texas Press, Austin, 257 p.

Smith, L. M., Haukos, D. A., McMurry, S. T., LaGrange, T., and Willis, D., 2011, Ecosystem services provided by playas in the High Plains: Potential influences of USDA conservation programs: Ecological Applications, v. 21, p. 82-92.

Sophocleous, M., 2005, Groundwater recharge and sustainability in the High Plains aquifer in Kansas, USA: Hydrogeology Journal, v. 13, p. 351-365.

Strahler, A. N., 1957, Quantitative analysis of watershed geomorphology: Eos, Transactions American Geophysical Union, v. 38, p. 913-920.

Syed, K. H., Goodrich, D. C., Myers, D. E., and Sorooshian, S., 2003, Spatial characteristics of thunderstorm rainfall fields and their relation to runoff: Journal of Hydrology, v. 271, p. 1-21.

Tang, Z., Li, Y., Gu, Y., Jiang, W., Xue, Y., Hu, Q., LaGrange, T., Bishop, A., Drahota, J., and Li, R., 2016, Assessing Nebraska playa wetland inundation status during 1985-2015 using Landsat data and Google Earth Engine: Environmental Monitoring and Assessment, v. 188, p. 1-14.

Tsai, J.-S., Venne, L. S., McMurry, S. T., and Smith, L. M., 2007, Influences of land use and wetland characteristics on water loss rates and hydroperiods of playas in the Southern High Plains, USA: Wetlands, v. 27, p. 683-692.

U.S. Department of Agriculture Natural Resources Conservation Service, 2006, Land resource regions and major land resource areas of the United States, the Caribbean, and the Pacific Basin: U.S. Department of Agriculture Handbook 296, 667 p. 
Vose, R., Easterling, D. R., Kunkel, K., and Wehner, M., 2017, Temperature changes in the United States; in Climate Science Special Report: Fourth National Climate Assessment, Volume I: U.S. Global Change Research Program, Washington, D. C., p. 185-206.

Weeks, J. B., 1988, Summary of the High Plains regional aquifersystem analysis in parts of Colorado, Kansas, Nebraska, New
Mexico, Oklahoma, South Dakota, Texas, and Wyoming: U.S. Geological Survey Professional Paper 1400-A, 30 p.

Zhang, H., Tang, Z., Bishop, A., Drahota, J., LaGrange, T., and Varner, D., 2020, Conservation significantly improves wetland conditions: Evaluation of playa wetlands in different conservation status: Wetlands Ecology and Management, v. 28 , p. 85-102. 


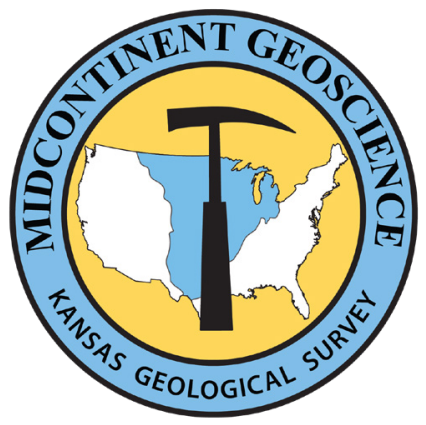

Midcontinent Geoscience • Volume 2・ July 2021 Tony Layzell - Editor

Technical Editor — Julie Tollefson

Suggested citation: Bowen, M. W., and Lepe, L., 2021, Examining patterns and drivers of variability in playa water status on the High Plains of western Kansas, 2016-2019: Midcontinent Geoscience, v. 2, p. 15-32.

Midcontinent Geoscience is an open-access, peer-reviewed journal of the Kansas Geological Survey. The journal publishes original research on a broad array of geoscience topics, with an emphasis on the midcontinent region of the United States, including the Great Plains and Central Lowland provinces.

Submission information: https:/ /journals.ku.edu/mg/about/submissions

Kansas Geological Survey 1930 Constant Avenue The University of Kansas Lawrence, KS 66047-3724 785.864.3965

http://www.kgs.ku.edu/

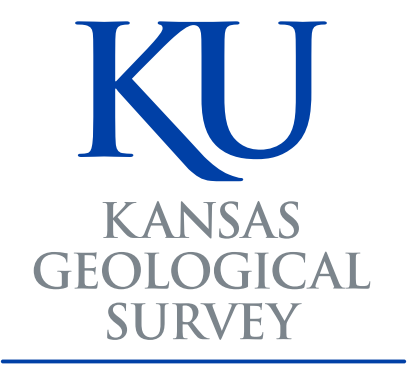

The University of Kansas 